\title{
The Use of Language Games in Enhancing ESL Learners' Sentence Construction
}

Dharshini Krishnan Morthy, Azlina Abdul Aziz

To Link this Article: http://dx.doi.org/10.6007/IJARBSS/v10-i9/7695

DOI:10.6007/IJARBSS/v10-i9/7695

Received: 09 June 2020, Revised: 10 July 2020, Accepted: 16 August 2020

Published Online: 14 September 2020

In-Text Citation: (Morthy, \& Abdul Aziz, 2020)

To Cite this Article: Morthy, D. K., \& Abdul Aziz, A. (2020). The Use of Language Games in Enhancing ESL Learners' Sentence Construction. International Journal of Academic Research in Business and Social Sciences, 10(9), 16-32.

\section{Copyright: (c) 2020 The Author(s)}

Published by Human Resource Management Academic Research Society (www.hrmars.com) This article is published under the Creative Commons Attribution (CC BY 4.0) license. Anyone may reproduce, distribute, translate and create derivative works of this article (for both commercial and non-commercial purposes), subject to full attribution to the original publication and authors. The full terms of this license may be seen

at: http://creativecommons.org/licences/by/4.0/legalcode

Vol. 10, No. 9, 2020, Pg. 16 - 32

Full Terms \& Conditions of access and use can be found at http://hrmars.com/index.php/pages/detail/publication-ethics 


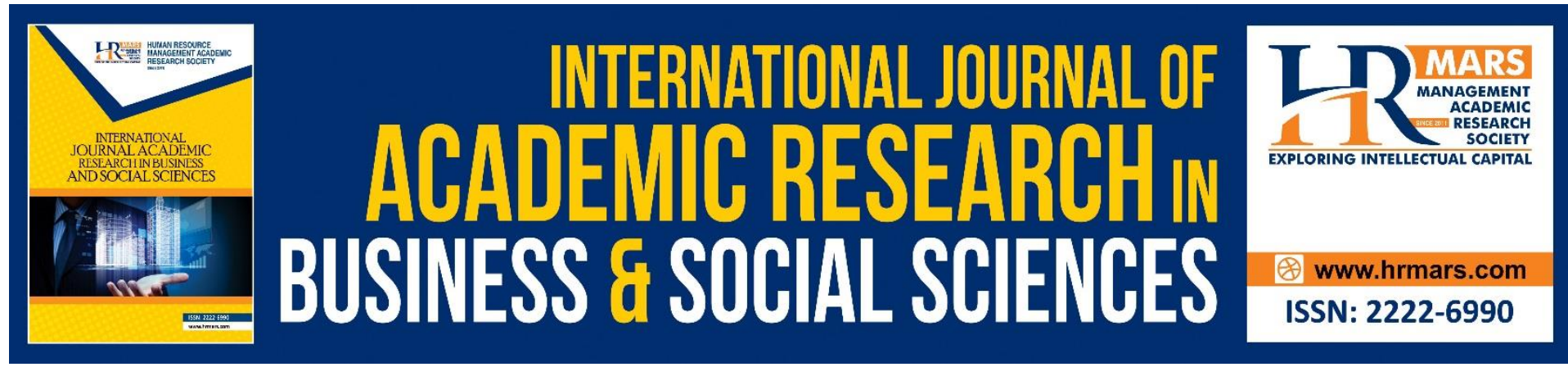

\title{
The Use of Language Games in Enhancing ESL Learners' Sentence Construction
}

\author{
Dharshini Krishnan Morthy, Azlina Abdul Aziz \\ Faculty of Education, Universiti Kebangsaan Malaysia (UKM), 43600 Bangi, Selangor, \\ Malaysia \\ Email: dharsh5krish@gmail.com, azlina1@ukm.edu.my
}

\begin{abstract}
This paper comprises a systematic review of relevant published studies from the year 2013 to 2020 on the use of language games in enhancing ESL learners' sentence construction. This systematic review aims to answer two research questions, i.e., what type of language games should be used with ESL learners to enhance their sentence construction and how do language games aid in teaching sentence construction effectively. Fifteen studies were systematically reviewed. Results indicate that both digital and non-digital language games are great tools to be used in a language classroom as it enhances ESL learners' sentence construction by boosting their motivation in a fun learning atmosphere. However, non-digital language games are considered to be easier to employ as it does not require ICT. The limitation of the reviewed studies and suggestion for further research was discussed.
\end{abstract}

Keywords: Language Games, Digital, Non-digital, ESL, Sentence Construction.

\section{Introduction}

Writing is a kind of communication that permits learners to disclose their ideas and feelings through a well-devised text. It is widely contemplated as a critically paramount skill in the teaching and learning of English as a Second Language (ESL). It helps to solidify all other language skills of listening, speaking and reading (Saed \& AL-Omari, 2014) as it is a comprehensive skill that enhances vocabulary, grammar, thinking, planning, editing, revising and other elements (len et al, 2017).

In addition, writing is regarded as one of the most strenuous language skills learners are anticipated to ace (Nik et al, 2010; Majid et al, 2015) since it prompts intellectual growth. Learners connect their prior knowledge with new information and fine-tune their ideas (Kaur, 2014) to express themselves victoriously in the process of writing. Therefore, it is propagated as a tool to measure learners' knowledge (Kurniati, 2015 as cited in Abdullah \& Yunus, 2019). Moreover, writing is considered a prerequisite in a broader context of life beyond the classroom. There is a saying "reading makes a full man, conference a ready man and writing an exact man". Likewise, mastering writing skill will not only aid learners in achieving success in national examinations like Primary School Achievement Test (UPSR), Lower Secondary Assessment (PMR), Malaysian Certificate of Education (SPM) and Malaysian Higher School Certificate (STPM) but also prepares them to be equipped for the workforce and the global 
economy (Lim, 2013). Therefore, acquiring writing skill yields a lifelong holistic gain for the learners.

The Core of a Good Sentence

A good sentence needs to make sense on its own (McLean, 2012). Generally, sentences are made up of clauses: groups of words that express a single idea (Gambrill, 2014). Independent clauses and dependent clauses are the two types of clauses. Clause that can represent a complete thought is known as independent clause whilst dependent clause requires an independent clause to keep intact its meaning. Simple sentence, compound sentence and complex sentence are made up of these two types of clauses. A sentence that consists of one independent clause is a simple sentence. Joining simple sentences will make up compound sentence and complex sentence is made when an independent clause and a dependent clause are merged. Apart from that, a good sentence needs to be correctly punctuated (Krupa, 2013). It always starts with a capital letter and either a full stop, exclamation or question mark will be used at the end.

\section{Poor Sentence Construction Among ESL Learners}

Simple sentence construction is a very fundamental thing that learners need to grasp by the first three years of schooling. When they failed to do it, they tend to have more complex problems in regards to writing compound and complex sentences (Miin et al, 2019) in the subsequent years. Evidently, Malaysian former education director-general, Khair Mohamad Yusof declared that pupils have yet to achieve a level desired for writing in the English language as 23 percent of pupils had flunked in their English written paper in the Primary School Achievement Test (UPSR) in 2016 ("New UPSR format", 2016).

Several grounds have contributed to poor sentence construction among Malaysian ESL learners. Firstly, less exposure to the language. Many pupils are being exposed to the target language only in the school during the English periods. They have a minimal space to practice, acquire and polish the language. Despite of utilizing the golden time fruitfully, some tend to utter using their mother tongue within their peers during the class (Ghabool et al, 2012). This often acts as a hindrance to their learning.

Furthermore, the teaching method being employed by the teachers does not help in provoking a fun learning atmosphere (Li \& Yee, 2017). Many teachers are still using chalk and talk method instead of keeping up with the latest methodologies. Interesting teaching methods that suit the pupils' learning styles need to be employed in order to heighten their level of motivation in acquiring the target language (Li \& Razali, 2019). When the teachers fail to exercise the right method of teaching, they eventually fail to provide a pleasant atmosphere to motivate and attract pupils' interest in acquiring the language. Subsequently, results in poor language acquisition, particularly in writing sentences.

To confront the poor sentence construction among ESL learners, there is a need to discover a teaching method that can turn the learning environment to be fun and useful. The literature has shown that language games can enhance learners' sentence construction.

\section{Research Objectives and Research Questions}

The prime objective of this systematic review is

To present a synthesis of empirical evidence discovered in the past related studies on the use of language games in enhancing ESL learners' sentence construction to researchers and 
writing teachers so that further intervention development and research in this area can be conducted.

This study is carried out to answer the following research questions:

What type of language games should be used to ESL learners to enhance their sentence construction?

How do language games aid in teaching sentence construction effectively?

\section{Literature Review \\ Definition of Language Game}

A language game is defined as an activity that is used to facilitate the learning of a language (Yaccob \& Yunus, 2019).

\section{Importance of Language Game}

Xeni (2014) asserted that "children learn language best in an environment rich with opportunities to explore interesting objects and ideas" (p.197). In this context, games are assured to be beneficial (Taheri, 2014) as it creates an exciting and fun learning atmosphere. In other words, language games provide room for learners to acquire the target language actively in a non-threatening learning environment.

In addition, language games are embedded with the motivating elements. The Flow Theory by Mihaly Csikszentmihaly in 1975 is established when learners are learning through language games as they gain a motivational stimulus to focus on accomplishing the tasks (Yaccob \& Yunus, 2019). As they work towards it, they are indirectly acquiring the target language through hands-on learning, which will result in longer memory retention. This is further supported by Godwin-Jones (2014). He stated that "game playing can be a powerful agent for learner autonomy, a potential resource for long-term language maintenance and an entry-point for gaining interest in learning new languages" (p.11). Therefore, language games are regarded as a great retreat for the learners from the traditional method of teaching and learning.

\section{Types of Language Games}

According to Yaccob and Yunus (2019), there are two types of language games, namely digital game and non-digital language game.

\section{Digital Language Game}

The advancement of technologies has brought new prospects for learning in the educational context. The incorporation of the Information and Communication Technology (ICT) in the language game is known as digital language game ( $\mathrm{Xu}$ et $\mathrm{al}, 2019)$. It is considered to be attractive due to its entertaining features, aesthetic quality (graphics, effects, music), the existence of a structured framework, the learning goals and the presence of the gaming dimension (Manesis, 2020). However, to utilize digital language games, schools need to be equipped with proper ICT facilities.

\section{Non-Digital Language Game}

Maloney (2019) defined a non-digital language game as the traditional game that does not require the use of ICT. She added that this type of game could be an excellent way to practice skills. Non-digital language games can be conducted anywhere and involve minimal cost as it can be made up of recycling items. 


\section{Method}

The systematic review was conducted by involving the four procedures proposed by Jain and Sharma (2016). The first procedure was to formulate the objective of the review, which has been done at the initial stage. Finding various studies that utilized language games in enhancing sentence construction was the second step. Before presenting the findings, the validity of the past studies was assessed.

Google Scholar, Educational Resources Information Centre (ERIC), Science Direct, Scopus, Human Resource Management Academic Research Society (HRMARS) and JSTOR were the international online bibliographic databases used to find research articles written in English published between years 2013 and 2020 (research carried out over the past eight years). The combination of key terms used to search for the past related studies were: (language games) and (digital OR non-digital language game) and (ESL learners OR EFL learners) and (writing difficulties) and (struggling writers OR less skilled writers) and (sentence construction). The studies found were later screened and shortlisted with heed to the inclusion criteria as follows:

1) The studies should focus on the use of language games in enhancing sentence construction.

2) The studies could employ qualitative, quantitative, mixed-method research, quasiexperimental study or case study as the research designs.

3) The studies should be conducted in teaching English as a Second Language (ESL) or teaching English as a Foreign Language (EFL) context.

4) All the participants or respondents in the study could be at their primary, secondary or tertiary level.

\section{Results and Discussion}

A total of three systematic reviews and twelve past related studies on language games in enhancing sentence construction from the year 2013 to 2020 were shortlisted after following the procedures mentioned above. The empirical evidence to support the use of language games in enhancing ESL learners' sentence construction are summarised in Table 1,2 and 3 as follows: 
INTERNATIONAL JOURNAL OF ACADEMIC RESEARCH IN BUSINESS AND SOCIAL SCIENCES

Vol. 10, No. 9, 2020, E-ISSN: 2222-6990 @ 2020 HRMARS

\begin{tabular}{|c|c|c|c|c|c|c|}
\hline $\begin{array}{l}\text { Article/ } \\
\text { Study }\end{array}$ & $\begin{array}{l}\text { Number of } \\
\text { Participants/ } \\
\text { Studies }\end{array}$ & $\begin{array}{l}\text { Research } \\
\text { Design }\end{array}$ & $\begin{array}{l}\text { Type of } \\
\text { Intervention }\end{array}$ & $\begin{array}{l}\text { Language } \\
\text { Game }\end{array}$ & $\begin{array}{l}\text { Total Hours } \\
\text { of } \\
\text { Intervention }\end{array}$ & Results \\
\hline $\begin{array}{l}\text { Miin et } \\
\text { al. } \\
\text { (2019) }\end{array}$ & $\begin{array}{l}30 \text { GALUS } \\
\text { (marginal } \\
\text { passing rate) } \\
\text { pupils }\end{array}$ & $\begin{array}{l}\text { Action } \\
\text { Research }\end{array}$ & $\begin{array}{l}\text { Digital } \\
\text { Language } \\
\text { Game }\end{array}$ & $\begin{array}{l}\text { Google } \\
\text { Docs: Step } \\
\text { by step } \\
\text { sentence } \\
\text { construction }\end{array}$ & 2 cycles & $\begin{array}{l}\text { - Pupils felt } \\
\text { more } \\
\text { confident to } \\
\text { expand a } \\
\text { word to a } \\
\text { complete } \\
\text { sentence. } \\
\text { - Immediate } \\
\text { feedback by } \\
\text { the teachers } \\
\text { enabled the } \\
\text { pupils to } \\
\text { realise their } \\
\text { mistakes } \\
\text { and to make } \\
\text { correction. } \\
\text { GoogleDocs } \\
\text { is easier, } \\
\text { more } \\
\text { interesting } \\
\text { and } \\
\text { motivates } \\
\text { pupils' to } \\
\text { write. }\end{array}$ \\
\hline $\begin{array}{l}\text { Yunus } \\
\text { et al. } \\
(2019)\end{array}$ & $\begin{array}{l}14 \text { Year } 5 \\
\text { pupils with } \\
\text { low to } \\
\text { intermediate } \\
\text { proficiency } \\
\text { levels }\end{array}$ & $\begin{array}{l}\text { Action } \\
\text { Research }\end{array}$ & $\begin{array}{l}\text { Digital } \\
\text { Language } \\
\text { Game }\end{array}$ & InstaWrite & 1 cycle & $\begin{array}{l}\text { The instant } \\
\text { feedback } \\
\text { given in } \\
\text { InstaWrite } \\
\text { has enabled } \\
\text { the } \\
\text { participants } \\
\text { to } \\
\text { immediately } \\
\text { learn and } \\
\text { correct their } \\
\text { mistakes. } \\
\text { Pupils } \\
\text { enjoyed the } \\
\text { process of } \\
\text { using } \\
\text { technology } \\
\text { than } \\
\text { conventional } \\
\text { way. }\end{array}$ \\
\hline
\end{tabular}




\begin{tabular}{|c|c|c|c|c|c|c|}
\hline $\begin{array}{l}\text { Al- } \\
\text { Naibi } \\
\text { et al. } \\
(2018)\end{array}$ & $\begin{array}{l}25 \text { students } \\
\text { of } \\
\text { foundation } \\
\text { programme } \\
\text { at Arab } \\
\text { Open } \\
\text { University }\end{array}$ & $\begin{array}{l}\text { Action } \\
\text { Research }\end{array}$ & $\begin{array}{l}\text { Digital } \\
\text { Language } \\
\text { Game }\end{array}$ & EDMODO & $\begin{array}{l}3 \text { lesson } \\
\text { plans }\end{array}$ & $\begin{array}{l}\text { - Gave } \\
\text { students } \\
\text { extra time to } \\
\text { practice } \\
\text { using English } \\
\text { outside the } \\
\text { classroom. } \\
\text { - Students are } \\
\text { comfortable } \\
\text { using it as } \\
\text { it's easy and } \\
\text { has friendly } \\
\text { interface like } \\
\text { Facebook } \\
\text { that } \\
\text { students are } \\
\text { familiar } \\
\text { with. }\end{array}$ \\
\hline
\end{tabular}

\begin{tabular}{|c|c|c|c|}
\hline $\begin{array}{l}\text { Article/ } \\
\text { Study }\end{array}$ & $\begin{array}{l}\text { Number of } \\
\text { Participants/ } \\
\text { Studies }\end{array}$ & Research Design & $\begin{array}{l}\text { Results (Pros and Cons of Language } \\
\text { Game) }\end{array}$ \\
\hline $\begin{array}{l}\text { Yaccob \& } \\
\text { Yunus } \\
\text { (2019) }\end{array}$ & 23 studies & $\begin{array}{l}\text { Comprehensive } \\
\text { Review }\end{array}$ & $\begin{array}{l}\text { - It stimulates learners' interest on } \\
\text { learning, develops fluency and } \\
\text { motivates to learn. }\end{array}$ \\
\hline $\begin{array}{l}\text { Wang \& } \\
\text { Dostal } \\
(2018)\end{array}$ & 12 studies & $\begin{array}{l}\text { Comprehensive } \\
\text { Review }\end{array}$ & $\begin{array}{l}\text { - It enables learners to have fun by } \\
\text { making learning happy and pleasant. } \\
\text { - Multisensory involvement in learning } \\
\text { provides longer retention. } \\
\text { - Immediate feedbacks given helps } \\
\text { learners to learn quickly and correct } \\
\text { their mistakes. }\end{array}$ \\
\hline $\begin{array}{l}\text { Ibrahim } \\
\text { (2017) }\end{array}$ & 6 studies & $\begin{array}{l}\text { Comprehensive } \\
\text { Review }\end{array}$ & $\begin{array}{l}\text { - It is considered as an anti-stress and } \\
\text { anxiety factor in the classroom, helping } \\
\text { learners remember things faster and } \\
\text { better. } \\
\text { - It is fun and entertaining. } \\
\text { - It enhances skills, linguistic knowledge } \\
\text { and focus on the use of language. } \\
\text { - It encourages shy learners to } \\
\text { participate. } \\
\text { - It builds collaborative learning. }\end{array}$ \\
\hline
\end{tabular}

Table 1: Summary of systematic reviews on the use of language game in enhancing sentence construction 
Table 2: Summary of the past related studies on the digital language game

\begin{tabular}{|c|c|c|c|c|c|c|}
\hline $\begin{array}{l}\text { Article/ } \\
\text { Study }\end{array}$ & $\begin{array}{l}\text { Number of } \\
\text { Participan } \\
\text { ts/ Studies }\end{array}$ & $\begin{array}{l}\text { Research } \\
\text { Design }\end{array}$ & $\begin{array}{l}\text { Type of } \\
\text { Interventi } \\
\text { on }\end{array}$ & $\begin{array}{l}\text { Languag } \\
\text { e Game }\end{array}$ & $\begin{array}{l}\text { Total } \\
\text { Hours of } \\
\text { Interventi } \\
\text { on }\end{array}$ & Results \\
\hline $\begin{array}{l}\text { Chamber } \\
\text { s \& } \\
\text { Yunus } \\
\text { (2017) }\end{array}$ & $\begin{array}{l}15 \text { Form } 5 \\
\text { lban } \\
\text { learners } \\
\text { who were } \\
\text { weak in } \\
\text { English }\end{array}$ & $\begin{array}{l}\text { Action } \\
\text { Research }\end{array}$ & $\begin{array}{l}\text { Non- } \\
\text { digital } \\
\text { language } \\
\text { game }\end{array}$ & $\begin{array}{l}\text { Wheel } \\
\text { of } \\
\text { Gramma } \\
r \text { (WOG) }\end{array}$ & - & $\begin{array}{l}\text { - Rebuild } \\
\text { better } \\
\text { confidence } \\
\text { among } \\
\text { learners. } \\
\text { - Self- } \\
\text { discovery } \\
\text { learning } \\
\text { through } \\
\text { the WOG is } \\
\text { fun and } \\
\text { enjoyable } \\
\text { compared } \\
\text { to those } \\
\text { printed in } \\
\text { textbooks. } \\
\text { - Learners } \\
\text { felt } \\
\text { motivated } \\
\text { in } \\
\text { completing } \\
\text { the task. }\end{array}$ \\
\hline $\begin{array}{l}\text { Sahathev } \\
\text { an \& } \\
\text { Yamat } \\
(2020)\end{array}$ & $\begin{array}{l}5 \text { Year } 3 \\
\text { pupils in } \\
\text { Subis, } \\
\text { Sarawak }\end{array}$ & $\begin{array}{l}\text { Quasi- } \\
\text { Experimen } \\
\text { tal Study }\end{array}$ & $\begin{array}{l}\text { Non- } \\
\text { digital } \\
\text { language } \\
\text { game }\end{array}$ & $\begin{array}{l}\text { Colourfu } \\
\text { I Jenga } \\
\text { Blocks } \\
\text { (CJB) }\end{array}$ & $\begin{array}{l}8 \text { writing } \\
\text { lessons } \\
\text { (1 hour } \\
\text { per } \\
\text { lesson) }\end{array}$ & $\begin{array}{l}\text { - CJB is } \\
\text { inculcate } \\
\text { the } \\
\text { element of } \\
\text { fun } \\
\text { interesting } \\
\text { in learning. } \\
\text { - CJB helps } \\
\text { increase } \\
\text { pupils' } \\
\text { vocabularie } \\
\text { s. } \\
\text { CJB assists } \\
\text { pupils in } \\
\text { understand } \\
\text { ing and } \\
\text { rememberi } \\
\text { ng } \\
\text { sentence } \\
\text { patterns as }\end{array}$ \\
\hline
\end{tabular}




\begin{tabular}{|c|c|c|c|c|c|c|}
\hline & & & & & & $\begin{array}{l}\text { well as } \\
\text { grammar } \\
\text { rules. }\end{array}$ \\
\hline $\begin{array}{l}\text { Jusun \& } \\
\text { Yunus } \\
\text { (2016) }\end{array}$ & $\begin{array}{l}13 \text { Year } 5 \\
\text { and } 9 \text { Year } \\
6 \text { pupils in } \\
\text { the district } \\
\text { of Lubok } \\
\text { Antu, } \\
\text { Sarawak. }\end{array}$ & $\begin{array}{l}\text { Action } \\
\text { Research }\end{array}$ & $\begin{array}{l}\text { Non- } \\
\text { digital } \\
\text { language } \\
\text { game }\end{array}$ & $\begin{array}{l}\text { Sentenc } \\
\mathrm{e} \\
\text { Makers }\end{array}$ & 5 weeks & $\begin{array}{l}\text { - It assisted } \\
\text { the lower- } \\
\text { competenc } \\
\text { e ESL } \\
\text { learners in } \\
\text { their ESL } \\
\text { writing as } \\
\text { it consists } \\
\text { of } \\
\text { segmented } \\
\text {, visual } \\
\text { sentence- } \\
\text { building } \\
\text { tool that is } \\
\text { easy to use } \\
\text { and } \\
\text { understand } \\
\text {. }\end{array}$ \\
\hline $\begin{array}{l}\text { Li \& Yee } \\
(2017)\end{array}$ & $\begin{array}{l}31 \text { pupils } \\
\text { of Year } 4\end{array}$ & $\begin{array}{l}\text { Action } \\
\text { Research }\end{array}$ & $\begin{array}{l}\text { Non- } \\
\text { digital } \\
\text { language } \\
\text { game }\end{array}$ & $\begin{array}{l}\text { Colourfu } \\
\text { I } \\
\text { Semanti } \\
\text { CS }\end{array}$ & $\begin{array}{l}\text { Four } \\
\text { weeks }\end{array}$ & $\begin{array}{l}\text { - It helped in } \\
\text { pupils' } \\
\text { sentence } \\
\text { constructio } \\
\text { n through } \\
\text { vocabulary } \\
\text { learning. } \\
\text { - Pupils } \\
\text { could write } \\
\text { sentences } \\
\text { with } \\
\text { correct } \\
\text { sequence. } \\
\text { - Pupils } \\
\text { enjoyed } \\
\text { and } \\
\text { motivated } \\
\text { to write } \\
\text { sentences. }\end{array}$ \\
\hline $\begin{array}{l}\text { len et al. } \\
(2017)\end{array}$ & $\begin{array}{l}16 \text { Year } 5 \\
\text { pupils of a } \\
\text { rural } \\
\text { school in } \\
\text { Belaga, } \\
\text { Sarawak }\end{array}$ & $\begin{array}{l}\text { Action } \\
\text { Research }\end{array}$ & $\begin{array}{l}\text { Non- } \\
\text { digital } \\
\text { language } \\
\text { game }\end{array}$ & $\begin{array}{l}\text { Build Me } \\
\text { Up }\end{array}$ & $\begin{array}{l}\text { Four } \\
\text { weeks } \\
\text { (8 hours) }\end{array}$ & $\begin{array}{l}\text { - It helped } \\
\text { the pupils } \\
\text { to write } \\
\text { grammatic } \\
\text { ally correct } \\
\text { sentences } \\
\text { by }\end{array}$ \\
\hline
\end{tabular}




\begin{tabular}{|c|c|c|c|c|c|c|}
\hline & & & & & & $\begin{array}{l}\text { understand } \\
\text { ing the } \\
\text { sentence } \\
\text { pattern } \\
\text { better. } \\
\text { - It has } \\
\text { moulded } \\
\text { the pupils } \\
\text { to be } \\
\text { independe } \\
\text { nt learners. }\end{array}$ \\
\hline $\begin{array}{l}\text { May \& } \\
\text { Said } \\
\text { (2019) }\end{array}$ & $\begin{array}{l}2 \text { classes } \\
\text { of Year } 4 \\
\text { (each class } \\
\text { consists of } \\
30 \text { pupils) }\end{array}$ & $\begin{array}{l}\text { Quasi- } \\
\text { Experimen } \\
\text { tal Study }\end{array}$ & $\begin{array}{l}\text { Non- } \\
\text { digital } \\
\text { language } \\
\text { game }\end{array}$ & $\begin{array}{l}\text { Innovati } \\
\text { on } \\
\text { Writing } \\
\text { kit }\end{array}$ & - & $\begin{array}{l}\text { - It helped } \\
\text { pupils to } \\
\text { master the } \\
\text { skill on } \\
\text { sentence } \\
\text { constructio } \\
\mathrm{n} \text { that } \\
\text { adhere to } \\
\text { Subject } \\
\text { Verb } \\
\text { Agreement } \\
\text { (SVA). } \\
\text { - It helped } \\
\text { them to } \\
\text { write } \\
\text { grammatic } \\
\text { ally correct } \\
\text { sentences } \\
\text { as it was } \\
\text { hands-on } \\
\text { based } \\
\text { activity. }\end{array}$ \\
\hline $\begin{array}{l}\text { Ling \& } \\
\text { Mohama } \\
\text { d (2018) }\end{array}$ & $\begin{array}{l}7 \text { Year } 5 \\
\text { pupils of a } \\
\text { school in } \\
\text { Bintulu, } \\
\text { Sarawak }\end{array}$ & Case Study & $\begin{array}{l}\text { Non- } \\
\text { digital } \\
\text { language } \\
\text { game }\end{array}$ & $\begin{array}{l}\text { Tree } \\
\text { Map }\end{array}$ & $\begin{array}{l}3 \text { weeks } \\
\text { ( } 6 \text { hours) }\end{array}$ & $\begin{array}{l}\text { - Pupils were } \\
\text { able to } \\
\text { identify } \\
\text { and } \\
\text { categorize } \\
\text { the given } \\
\text { keywords } \\
\text { precisely } \\
\text { and } \\
\text { construct } \\
\text { sentences } \\
\text { with } \\
\text { correct } \\
\text { structures. }\end{array}$ \\
\hline
\end{tabular}


- It aroused interest of

the

learners.

- Learners were

motivated

and gained

confidence

in

employing

the Tree

Map in

sentence

constructio

$\mathrm{n}$.

\begin{tabular}{llllll}
\hline Lau et al. & 8 Year 4 & Action & Non- & Rainbow & 2 weeks \\
(2019) & pupils & Research & $\begin{array}{l}\text { digital } \\
\text { language }\end{array}$ & Tower & (twice a \\
from 2 & & week) \\
& schools in & & & \\
& the & & & \\
interior of & & & \\
& Sarawak & & &
\end{tabular}

- The

- The participant

s can

construct

sentences

correctly or

at least

with

minimal

error.

- They were motivated

to learn

using an

interesting

language

game.

- It helped to gain their attention towards

learning and improved the learning environme nt for the students. 
INTERNATIONAL JOURNAL OF ACADEMIC RESEARCH IN BUSINESS AND SOCIAL SCIENCES Vol. 10, No. 9, 2020, E-ISSN: 2222-6990 @ 2020 HRMARS

\begin{tabular}{|c|c|c|c|c|c|c|}
\hline $\begin{array}{l}\text { Efendi \& } \\
\text { Wirabhak } \\
\text { ti (2018) }\end{array}$ & $\begin{array}{l}70 \text { eighth } \\
\text { grade } \\
\text { students } \\
\text { of SMPN } 4 \\
\text { Palimanan } \\
\text {-Cirebon }\end{array}$ & $\begin{array}{l}\text { Quasi } \\
\text { Experimen } \\
\text { tal Study }\end{array}$ & $\begin{array}{l}\text { Non- } \\
\text { digital } \\
\text { language } \\
\text { game }\end{array}$ & $\begin{array}{l}\text { Sentenc } \\
\text { e-Soup } \\
\text { Game } \\
\text { (SSG) }\end{array}$ & - & $\begin{array}{l}\text { - SSG made } \\
\text { the lesson } \\
\text { less } \\
\text { monotono } \\
\text { us and } \\
\text { raised } \\
\text { students' } \\
\text { motivation, } \\
\text { stimulated } \\
\text { students' } \\
\text { participatio } \\
\text { n and } \\
\text { increased } \\
\text { their } \\
\text { confidence } \\
\text { - } \\
\text { SSG caused } \\
\text { students' } \\
\text { closeness. }\end{array}$ \\
\hline
\end{tabular}

Table 3: Summary of the past related studies on the non-digital language game 
Three pertinent systematic reviews were discovered (Yaccob \& Yunus, 2019; Wang \& Dostal, 2018; Ibrahim, 2017) and the findings of these systematic reviews elucidated on the importance of using language games to assist struggling or beginning writers in the past years and it answered the second research question, i.e., how do language games aid in teaching sentence construction effectively as addressed initially in this paper. Yaccob and Yunus (2019) had conducted a comprehensive review of research comprising 23 studies which addressed the advantages of using language game in ESL context. On the other hand, Wang and Dostal (2018) and Ibrahim (2017) had utilized 12 studies and 6 studies respectively to enlighten the readers about the benefits that language games yield to the EFL learners in the process of acquiring the language.

Furthermore, there are some studies (Miin et al, 2019; Yunus et al, 2019; Al-Naibi et al, 2018) whereby the researchers focussed on employing digital language game in enhancing learners' sentence construction. The use of non-digital language game was concentrated too by Chambers and Yunus (2017); Sahathevan and Yamat (2020); Jusun and Yunus (2016); Li and Yee (2017); len et al. (2017); May and Said (2019); Ling and Mohamad (2018); Lau et al. (2019); Efendi and Wirabhakti (2018). Overall, it was found that language games enhanced learners' sentence construction among the participants.

\section{Language Game which should be used to ESL Learners to Enhance their Sentence Construction}

The outcomes of the twelve past related studies (Miin et al, 2019; Yunus et al, 2019; Al-Naibi et al, 2018; Chambers \& Yunus, 2017; Sahathevan \& Yamat, 2020; Jusun \& Yunus, 2016; Li \& Yee, 2017; len et al, 2017; May \& Said, 2019; Ling \& Mohamad, 2018; Lau et al, 2019; Efendi \& Wirabhakti, 2018) indicated that both digital and non-digital language game contributes equally in the enhancement of the learners' sentence construction. However, non-digital language game was the most preferred one as it could be employed anywhere since it does not require ICT facilities.

Miin et al. (2019), Yunus et al. (2019) and Al-Naibi et al. (2018) asserted that digital language games like "Google Docs", "Instawrite" and "EDMODO" had resulted in a significant enhancement in constructing sentences among the learners. Due to the integration of technology in the lesson, learners able to enjoy and feel motivated to learn (Yunus et al, 2019). The automated feedback given by digital language games aids the learners to realize their mistakes and correct them accordingly (Miin et al, 2019; Yunus et al, 2019). As the learners nowadays are tech-savvy, digital language games would interest them more as they feel comfortable and familiar with the usage of it (Al-Naibi et al, 2018). Learners also have the privilege of practicing the language outside the classroom with the use of a digital language game. However, it can only be done if the learners have access to ICT (Al-Naibi et al, 2018).

On the other hand, Chambers and Yunus (2017); Sahathevan and Yamat (2020); Jusun and Yunus (2016); Li and Yee (2017); len et al. (2017); May and Said (2019); Ling and Mohamad (2018); Lau et al. (2019); Efendi and Wirabhakti (2018) postulated that non-digital language games like "Wheel of Grammar", "Colourful Jenga Blocks", "Sentence Makers", "Colourful Semantics", "Build Me Up", "Innovation Writing Kit", "Tree Map", "Rainbow Tower" and "Sentence-Soup Game" are capable of enhancing ESL learners' sentence construction too. Non-digital language games tend to make the learning process more meaningful as it demands the active involvement of the learners (Chambers \& Yunus, 2017). They have to get involved by doing hands-on based activities like identify the part of the sentence and arrange it according to the sentence pattern (Ling \& Mohamad, 2018; Sahathevan \& Yamat, 2020; 
Jusun \& Yunus, 2016). This eventually assists the learners in their sentence construction by molding them to be independent learners (len et al, 2017). The most exciting part is learners can be benefitted from the use of non-digital language games regardless of the place as long as they know the rules (Lau et al, 2019).

\section{Language Game in Teaching Sentence Construction}

The literature (Yaccob \& Yunus, 2019; Wang \& Dostal, 2018; Ibrahim 2017) have highlighted on how language games aid in teaching sentence construction effectively. Language games are being used during the practice stage in a lesson after the introduction of the rules by the teacher to the learners (Yaccob \& Yunus, 2019). Learners are enabled to have fun while playing the language game (Wang \& Dostal, 2018). This results in happy and pleasant learning.

Multisensory involvement in learning provokes longer memory retention. Language games are regarded as a welcome break out of the conventional way (Ibrahim, 2017) that could build collaborative learning. It is also considered as an anti-stress task that incorporates the element of fun which eventually stimulates learners' interest and boost their motivation level in enhancing their sentence construction by helping the learners to remember things faster and better (Ibrahim, 2017; Yaccob \& Yunus, 2019). As the learners get familiar with the sentence structures by using the language games, subsequently they will be capable of constructing sentences independently that are grammatically correct (Sahathevan \& Yamat, 2020).

\section{Conclusion}

The findings of this review had enlightened on the most significant effects of language games in enhancing ESL learners' sentence construction. It was discovered that the use of language games had enhanced the learners' sentence construction in a meaningful and fun learning atmosphere (Miin et al, 2019; Yunus et al, 2019; Al-Naibi et al, 2018; Chambers \& Yunus, 2017; Sahathevan \& Yamat, 2020; Jusun \& Yunus, 2016; Li \& Yee, 2017; len et al, 2017; May \& Said, 2019; Ling \& Mohamad, 2018; Lau et al, 2019; Efendi \& Wirabhakti, 2018). In the long run, with a higher level of motivation and confidence, learners will be able to construct sentences without the aid of language games by just recalling the rules that have dwelled on their memory. Although both digital and non-digital language games bring similar results, nondigital language games are utilized and preferred by most of the researchers (Chambers \& Yunus, 2017; Sahathevan \& Yamat, 2020; Jusun \& Yunus, 2016; Li \& Yee, 2017; len et al, 2017; May \& Said, 2019; Ling \& Mohamad, 2018; Lau et al, 2019; Efendi \& Wirabhakti, 2018) as it does not rely on ICT facilities which many school are lacking in.

\section{Theoretical and Contextual Contribution}

This study is significant as it contributes to the stakeholders' understanding on the interplay between the language games and sentence construction. It enables the educators in maximizing a new teaching approach concerning the simple sentence construction. Furthermore, the findings shows that the non-digital language game is more pratical and applicable than the digital language game. It also contributes to the development of sentence construction among the pupils by stimulating their interest and motivation to learn. Last but not least, it is useful for the MOE in designing better teaching pedagogy. 


\section{References}

Abdullah, Y. L. P. K., \& Yunus, M. M. (2019). The Use of Pictures in Improving Students' Writing. Modern Journal of Language Teaching Methods (MJLTM), 1-8. doi: 10.26655/mjltm.2019.4.5

Al-Naibi, I., Al-Jabri, M., \& Ahmed, I. (2018). Promoting Students' Paragraph Writing Using EDMODO: An Action Research. Turkish Online Journal of Educational Technology - TOJET, 17(1), 130-143.

Chambers, G. J., \& Yunus, M. M. (2017). Enhancing Learners' Sentence Constructions via "Wheel of Grammar". Pertanika Journals Social Sciences \& Humanities, 25(4), 16411650.

Gambrill, P. (2014). Sentence Fragments. Retrieved from https://www.sjsu.edu/writingcenter/docs/ handouts/Fragments.pdf

Ghabool, N., Mariadass, M. E., \& Kashef, S. H. (2012). Investigating Malaysian ESL Students' Writing Problems on Conventions, Punctuation, and Language Use at Secondary School Level. Journal of Studies in Education, 2(3), 130-143. doi: 10.5296/jse.v2i3.1892

Ibrahim, A. (2017). Advantages of Using Language Games in Teaching English as a Foreign Language in Sudan Basic Schools. American Scientific Research Journal for Engineering, Technology and Sciences (ASRJETS), 37(1), 140-150.

len, L. K., Yunus, M. M., \& Embi, M. A. (2017). Build Me Up: Overcoming Writing Problems Among Pupils in A Rural Primary School in Belaga, Sarawak, Malaysia. Jurnal Pendidikan Humaniora, 5(1), 1-7. doi: 10.17977/um030v5i12017p001

Jain, S., \& Sharma, N. (2016). Guideline for systematic reviews. International Dental \& Medical Journal of Advanced Research, 2, 1-10. Doi: 10.15713/ins.idmjar.48

Jusun, K. D., \& Yunus, M. M. (2016). The Effectiveness of Using Sentence Makers in Improving Writing Performance among Pupils in Lubok Antu Rural Schools. International Conference on Education, 469-475.

Kaur, G. (2014). Use of Process Writing to Enhance Writing Abilities among Year 5 pupils. Retrieved from

http://www.fp.utm.my/epusatsumber/pdffail/ptkghdfwp2/gurminder kaurmp101511d2014ttp.pdf

Krupa, T. (2013). Is It Sometimes Okay to Begin a Sentence with a Lowercase Letter?. Retrieved from https://blog.apastyle.org/apastyle/2013/11/is-it-sometimes-okay-to-begin-asentence-with-a-lowercase-letter.html

Lau, J. L., Anthony, E. A., \& Yunus, M. M. (2019). Teaching Present Continuous Sentence with Rainbow Tower in Rural Primary School. International Journal of Academic Research in Business and Social Sciences, 9(2), 538-544. doi: 10.6007/IJARBSS/v9-i2/5588

Li, K. L., \& Razali, A. B. (2019). Idea Sharing: Process-Based Approach to Writing in Malaysian English Education. PASAA, 58(July-December), 317-339.

Li, K. L., \& Yee, T. J. (2017). The Use of Colourful Semantics to Improve Sentence Construction in Writing Sentences among Year Four Pupils. Journal of English Education, 2(1), 43-50.

Lim, T. D. (2013). Analyzing Malaysian English Classrooms: Reading, Writing, Speaking and Listening Teaching Strategies. https://digital.lib.washington.edu/ researchworks/bitstream/handle/1773/25020/Lim_washington_02500_12452.pdf

Ling, T. M., \& Mohamad, M. (2018). Effects of Tree Map in the Teaching of Sentence 
Construction among Upper Primary Pupils. International Journal of Innovative Research and Creative Technology, 4(6), 126-133.

Majid, A. H. A., Stapa, S. H., \& Keong, Y. C. (2015). Blended Scaffolding Strategies

Through Facebook for Learning and Improving the Writing Process and Writing Performance. Journal of Social Sciences and Humanities, (1), 31-39.

Maloney, S. (2019). Gamification in English language teaching: more than child's play. Retrieved from https://hongkongtesol.com/blog/2019/07/gamification-englishlanguage-teaching-more-childs-play

Manesis, D. (2020). Digital Games in Primary Education. Retrieved from https://www.intechopen.com/books/game-design-and-intelligentinteraction/digital-games-in-primary-education

May, T. M., \& Said, N. E. M. (2019). Effects of writing kit innovation on ESL learners' sentence construction. International Journal of Academic research in Business \& Social Sciences, 9(12), 292-300. doi: 10.6007/IJARBSS/v9-i12/6724

McLean, S. (2012). Successful writing. Retrieved from https://2012books.lardbucket.org/pdfs/succes sfull-writing.pdf

Miin, W. P., Rou, L. Y., \& Yunus, M. M. (2019). Google Docs: Step by Step Sentence Construction for Primary School Marginal Passing Rate Pupils. Creative Education, 10(2), 237-245. doi: 10.4236/ce.2019.102019

New UPSR format sees big drop in straight A scorers. (2016). The Star, Education. Retrieved from https://www.thestar.com.my/news/nation/2016/11/18/new-upsr-format-sees-bigdrop-in-straight-a scorers/

Saed, H. A., \& AL-Omari, H. A. (2014). The Effectiveness of a Proposed Program Based on a Mind Mapping Strategy in Developing the Writing Achievement of Eleventh Grade EFL Students in Jordan and Their Attitudes Towards Writing. Journal of Education and Practice, 5(18), 88-109.

Sahathevan, E. V., \& Yamat, H. (2020). Learning Simple Sentence Construction Using Colourful Jenga Blocks. International Journal of Academic Research in Progressive Education \& Development, 9(1), 1-14. http://dx.doi.org/10.6007/IJARPED/v9-i1/6824

Taheri, M. (2014). The Effect of Using Language Games on Vocabulary Retention of Iranian Elementary EFL Learners. Journal of Language Teaching and Research, 5(3), 544-549.

Wang, X., \& Dostal, J. (2018). Using Digital Educational Games for English Foreign Language Learning. Proceedings of EDULEARN18 Conference 2nd-4th July 2018. doi: 10.21125/edulearn.2018.0060

Xeni, E. (2015). Making Sense of Learners Making Sense of Written Language: The Selected Works of Kenneth S. Goodman and Yetta M. Educational Media International, 52(1), 59-61. doi: 10.1080/09523987.2015.1008781

Xu, Z., Chen, Z., Eutsler, L., Geng, Z., \& Kogut, A. (2019). A scoping review of digital game-based technology on English language learning. Educational Technology Research and Development, 68, 877-904.

Yunus, M. M., May, T. M., \& Mohideen, M. A. K. (2019). Writing Essays Made Easy with Instawrite. International Journal of Academic Research in Business and Social Sciences, 9(1), 331-344. doi: 10.6007/IJARBSS/v9-i1/5401 
INTERNATIONAL JOURNAL OF ACADEMIC RESEARCH IN BUSINESS AND SOCIAL SCIENCES

Vol. 10, No. 8, 2020, E-ISSN: 2222-6990 @ 2020 HRMARS

Yaccob, N. S., \& Yunus, M. M. (2019). Language Games in Teaching and Learning English Grammar: A Literature Review. Arab World English Journal, 10(1), 209-217. doi: 10.24093/awej/vol10no1. 18 